DOI: http://dx.doi.org/10.18203/2320-1770.ijrcog20201792

Original Research Article

\title{
Swine flu awareness in pregnancy
}

\author{
Nilesh Doshi $^{1}$, Aditi J. Upadhye ${ }^{2}$, Jayshree J. Upadhye ${ }^{1 *}$
}

\begin{abstract}
${ }^{1}$ Department of Obstetrics and Gynecology, Varun Arjun Medical College, Banthara, Shahjahanpur, Uttar Pradesh, India

${ }^{2}$ Department of Obstetrics and Gynecology, Varun PDMMC, Amravati, Maharashtra, India
\end{abstract}

Received: 18 February 2020

Revised: 01 April 2020

Accepted: 09 April 2020

\section{*Correspondence:}

Dr. Jayshree J. Upadhye,

E-mail: jayshreeupadhye@gmail.com

Copyright: ( $)$ the author(s), publisher and licensee Medip Academy. This is an open-access article distributed under the terms of the Creative Commons Attribution Non-Commercial License, which permits unrestricted non-commercial use, distribution, and reproduction in any medium, provided the original work is properly cited.

\begin{abstract}
Background: Swine influenza outbreaks are common in pigs year-round and infection in humans is a result of close contact with infected animals. Understanding the perception of the public and their potential resources would help public health agencies in developing educational programs to increase the awareness of the public. The objective of this study was to assess the knowledge, attitude and practices on different aspects of swine flu.

Methods: A cross-sectional study of 100 pregnant women was conducted at Varun Arjun Medical College, Banthara, Shahjahanpur, Uttar Pradesh, India to test their knowledge, attitudes, and use of precautionary measures against influenza infection.

Results: In this study, 98 (98\%) of pregnant women were aware of swine flu infection, 85 (85\%) of pregnant women knew that swine flu is due to viral infection while $65(65 \%)$ of pregnant women were aware that swine flu infection spreads through air while sneezing and coughing. In this study, $95(96 \%)$ of pregnant women knew fever as symptom of swine flu, $83(83 \%)$ of pregnant women knew cough and cold as symptoms while 64 (64\%) of pregnant women knew headache and body ache as symptoms. 94 (94\%) of pregnant women were aware that vaccination against swine flu can prevent swine flu infection. $80(80 \%)$ of pregnant women knew that covering mouth and nose while coughing and sneezing can prevent spread of swine flu infection while $52(52 \%)$ of pregnant women knew that frequent hand washing helps in preventing spread of swine flu infection. $76(76 \%)$ of pregnant women received vaccination against swine flu while 24 (24\%) of pregnant women did not receive vaccination against swine flu.

Conclusions: Learning more about the knowledge, attitudes, and behaviors of the public during swine flu and other infectious disease outbreak can be crucial to improve efforts by public health officials and clinicians.
\end{abstract}

Keywords: Infection, Knowledge, Pregnancy, Prevention, Vaccination

\section{INTRODUCTION}

A novel influenza A (H1N1) or Swine flu emerged from Mexico caused the first pandemic of the century where $\mathrm{H}$ and $\mathrm{N}$ stands for two surface proteins of the virus. ${ }^{1}$

Changes in immune function during pregnancy alter a pregnant woman's susceptibility to certain infectious diseases. Influenza infections cause more severe illness and higher mortality rates for pregnant women. Also, other physiologic changes in pregnancy like increased heart rate, stroke volume, and oxygen consumption along with decreased lung capacity may contribute to the increased risk for illness during pregnancy. Due to the high risk for influenza-related complications, all women during the influenza season should be vaccinated. ${ }^{2}$

Physicians may hesitate to give vaccination or aggressive treatment to pregnant women due to concerns about effects on the fetus. As per 1997 recommendation, all 
women in their second or third trimester of pregnancy during influenza season should receive the inactivated influenza vaccine. ${ }^{2}$

Hospital admission and mortality rates for swine flu were higher for pregnant women than in the general population during the 2009 pandemic; Infected pregnant women had increased rates of stillbirth, perinatal and neonatal mortality than their non-infected counterparts. ${ }^{3}$

The path physiology of increased influenza-related morbidity during pregnancy is not fully understood. An altered immune response to infection in pregnancy may contribute. ${ }^{4}$

Pregnant women are considered as a high-risk group. They have enhanced susceptibility to develop pneumonia and/or acute respiratory distress syndrome. They are four times more likely to be hospitalized when they have H1N1v flu as compared to the general population. CDC recommends that pregnant women should be treated with antiviral drugs as soon as symptoms appear. It should be started preferably within 48 hours of onset of the illness. ${ }^{5}$

The World Health Organization (WHO) have stated that pregnant women should be prioritized to receive the swine flu vaccines when these are available. ${ }^{5}$

Good personal and household hygiene measures are important in preventing the spread of the virus. Frequent hand washing or cleaning with a disinfectant is highly effective in preventing the spread of the virus. Parents should also ensure that they wash their babies' hands. Tissues should be used to cover the mouth and nose when sneezing and coughing. All used tissues should be disposed of promptly. ${ }^{6}$

The most important step to take in pregnancy is to treat high fever. This can be controlled by taking paracetamol which is safe in pregnancy. Plenty of fluids should be taken. Antiviral medicine as prescribed should be taken. 6

Antiviral drugs do not a cure, but shorten the illness. It also reduces the risk of complications, especially if the course is begun within 48 hours of symptoms developing. The H1N1 virus is known to be susceptible to two antiviral drugs namely oseltamivir (Tamiflu) and zanamivir (Relenza). ${ }^{6}$

Women who are breastfeeding will usually be given Tami flu if they need an antiviral medicine because there is no longer a risk to the placenta or developing baby. Relenza also is safe for women to breastfeed. ${ }^{6}$

Investigations like CBC, LFTs, RFTs, coagulation profile, X-ray chest, CT scan are done when required. Real-time reverse transcriptase (RT-PCR) is done for confirmation of diagnosis. Clinical specimens like nasopharyngeal swab, throat swab, nasal swab and tracheal aspirate in intubated patients are to be obtained preferably before starting the anti-viral drug. ${ }^{7}$

Oseltamivir is the recommended and safe drug both for prophylaxis and treatment. Dose is $75 \mathrm{mg}$ BD for 5 days for adults. It is safe in pregnancy in all trimesters. Supportive therapy is given as symptomatic treatment like IV fluids, parenteral nutrition, oxygen therapy/ ventilator support. Paracetamol is prescribed for fever, myalgia and headache. Salicylate/aspirin is strictly contra-indicated in any influenza patient due to its potential to cause Reye's syndrome. Antibiotics should be given if required.

FDA has approved the H1N1 monovalent vaccine as intramuscular injection (inactivated) and an intranasal spray (Live). Inactivated vaccine is administered to individuals above 6 months. It is safe and recommended for pregnant women. ${ }^{7}$

In postpartum period, mother should be temporarily separated from the new-born within her room OR in a separate room until the risk of infection transmission is reduced. $^{7}$

The risk is reduced when all of the following criteria are met-

- Mother has received antiviral medications for at least 48 hours.

- Mother is without fever for 24 hours without antipyretics.

- Mother can control cough and respiratory secretions.

After this, mother and the new-born can have close contact throughout the postpartum period with droplet precautions. Mother can also start breast feeds. ${ }^{7}$

H1N1 influenza has been identified as a cause of febrile respiratory infection worldwide. In India, the highest number of cases was reported in 2009 (27,236), followed by $2010(20,604)$ and $2012(5,054$ cases $)$. The highest number of swine flu deaths took place in $2011(1,763)$, followed by 2009 (981) and 2012 (405). ${ }^{8}$

Pregnancy is associated with increased risk of hospital, intensive care unit admission and death. Pregnant women who receive delayed treatment with neuraminidase inhibitors or who had additional risk factors are more likely to develop severe disease. Preterm and emergency caesarean deliveries are frequently reported. So, there is importance of early identification and treatment of suspected influenza in this high-risk population. ${ }^{9}$

Every unhealthy woman needs to be classified by their signs and symptoms according to Triage scale. Hospitalization has to be done only if the situation gets worse or if a chronic disease complicates it like diabetes, AIDS, heart disease, asthma, obesity, etc. According to the scale, she needs to be isolated at her home and start a 
symptomatic treatment. Antiviral medications should be given only in suspicious pandemic influenza cases. If respiratory pathology gets worse the patient should be hospitalized immediately in a unit with the proper equipment. Every citizen must receive the A H1N1 vaccine. Pregnant women and breastfeeding women should be given priority. Pregnant women should receive the vaccine in any trimester but especially in the last trimester to prevent maternal and fetal complications. ${ }^{10}$

\section{Aims and objectives}

- To know whether the pregnant women had enough knowledge about swine flu (H1N1).

- To assess their knowledge about possible preventive measures to be taken including vaccination against swine flu.

\section{METHODS}

A cross-sectional study assessing the knowledge, attitudes and practices regarding Swine flu was performed at Varun Arjun Medical College, Banthara, Shahjahanpur, Uttar Pradesh, India. among pregnant women. Pregnant women aged 20-45 years during the period November to December 2017, formed the sample population. Using convenience sampling, 100 study pregnant women were approached and verbal consent for a face-to-face interview was sought.

\section{Inclusion criteria}

- Pregnant women aged 20-45 years.

\section{Exclusion criteria}

- Pregnant women $<20$ and $>45$ years

- Pregnant women Residents who failed to respond to all questions or who left before completing the interview.

Face-to-face interview was based on a pretested questionnaire

Table 1: Questionnaire.

\begin{tabular}{|ll|}
\hline \multicolumn{2}{|l|}{ Questionnaire } \\
\hline 1 & Name \\
\hline 2 & Age \\
\hline 3 & Awareness of swine flu infection \\
\hline 4 & Cause of swine flu \\
\hline 5 & Symptoms of swine flu \\
\hline 6 & Practices to prevent swine flu \\
\hline 7 & Whether received vaccination \\
\hline
\end{tabular}

\section{It included three essential questions}

1. Mode of spread of swine flu.

2. Common symptoms.
3. Preventive measures against the swine flu.

Questionnaire included detail information regarding patient, their attitude and practices regarding swine flu.

\section{Statistical analysis}

Data was collected in Microsoft excel sheet and analysed. Statistical analysis was done in percentages.

\section{RESULTS}

In this study, $52(52 \%)$ of pregnant women were from 2630 years, $23(23 \%)$ pregnant women were from 31-35 years, $12(12 \%)$ of pregnant women were from 20-25 years of age, $10(10 \%)$ pregnant women were from 36-40 years while $3(3 \%)$ of pregnant women were from 41-45 years of age (Table 2).

Table 2: Age distribution.

\begin{tabular}{|lll|}
\hline $\begin{array}{l}\text { Age } \\
\text { distribution }\end{array}$ & $\begin{array}{l}\text { No. of pregnant } \\
\text { women }\end{array}$ & Percentage \\
\hline 20-25 years & 12 & $12 \%$ \\
\hline 26-30 years & 52 & $52 \%$ \\
\hline $31-35$ years & 23 & $23 \%$ \\
\hline $36-40$ years & 10 & $10 \%$ \\
\hline $41-45$ years & 3 & $3 \%$ \\
\hline
\end{tabular}

Table 3: Awareness of swine flu and its transmission.

\begin{tabular}{|lll|}
\hline $\begin{array}{l}\text { Awareness of swine flu } \\
\text { and its transmission }\end{array}$ & $\begin{array}{l}\text { No. of } \\
\text { pregnant } \\
\text { women }\end{array}$ & Percentage \\
\hline Awareness of swine flu & 98 & $98 \%$ \\
\hline $\begin{array}{l}\text { Viral infection is the } \\
\text { cause }\end{array}$ & 85 & $85 \%$ \\
\hline $\begin{array}{l}\text { Spread by coughing and } \\
\text { sneezing through air }\end{array}$ & 65 & $65 \%$ \\
\hline
\end{tabular}

In this study, 98 (98\%) of pregnant women were aware of swine flu infection, 85 (85\%) of pregnant women knew that swine flu is due to viral infection while $65(65 \%)$ of pregnant women were aware that swine flu infection spreads through air while sneezing and coughing (Table 3).

Table 4: Awareness of symptoms.

\begin{tabular}{|lll|}
\hline $\begin{array}{l}\text { Awareness of } \\
\text { symptoms }\end{array}$ & $\begin{array}{l}\text { No. of pregnant } \\
\text { women respondents }\end{array}$ & Percentage \\
\hline Fever & 96 & $96 \%$ \\
\hline Cough and cold & 83 & $83 \%$ \\
\hline $\begin{array}{l}\text { Headache and } \\
\text { body ache }\end{array}$ & 64 & $64 \%$ \\
\hline
\end{tabular}

In this study, $95(96 \%)$ of pregnant women knew fever as symptom of swine flu, $83(83 \%)$ of pregnant women knew cough and cold as symptoms while $64(64 \%)$ of 
pregnant women knew headache and body ache as symptoms (Table 4).

Table 5: Awareness of prevention of swine flu.

\begin{tabular}{|lll|}
\hline $\begin{array}{l}\text { A wareness of prevention } \\
\text { of swine flu }\end{array}$ & $\begin{array}{l}\text { No. of } \\
\text { pregnant } \\
\text { women }\end{array}$ & Percentage \\
\hline Vaccine & 94 & $94 \%$ \\
\hline $\begin{array}{l}\text { Covering mouth and nose } \\
\text { while coughing and } \\
\text { sneezing }\end{array}$ & 80 & $80 \%$ \\
\hline Frequent hand washing & 52 & $52 \%$ \\
\hline
\end{tabular}

In this study, 94 (94\%) of pregnant women were aware that vaccination against swine flu can prevent Swine flu infection. $80(80 \%)$ of pregnant women knew that covering mouth and nose while coughing and sneezing can prevent spread of swine flu infection while $52(52 \%)$ of pregnant women knew that frequent hand washing helps in preventing spread of swine flu infection (Table 5).

Table 6: Received swine flu vaccine.

\begin{tabular}{|l|l|l|}
\hline $\begin{array}{l}\text { Received swine flu } \\
\text { vaccine }\end{array}$ & $\begin{array}{l}\text { No. of pregnant } \\
\text { women }\end{array}$ & Percentage \\
\hline Yes & 76 & $76 \%$ \\
\hline No & 24 & $24 \%$ \\
\hline
\end{tabular}

In this study, $76(76 \%)$ of pregnant women received vaccination against swine flu while 24 (24\%) of pregnant women did not receive vaccination against swine flu (Table 6).

\section{DISCUSSION}

In this study, $52(52 \%)$ of pregnant women were from 2630 years, 23 (23\%) pregnant women were from 31-35 years, $12(12 \%)$ of pregnant women were from 20-25 years of age, $10(10 \%)$ pregnant women were from 36-40 years while $3(3 \%)$ of pregnant women were from 41-45 years of age (Table 2). Hanan HB et al found that out of 1,548 interviews, most of the participants were in the age groups of $18-24$ years $(53.2 \%)$ and $25-39$ years $(32.8 \%) .^{11}$

In this study, $98(98 \%)$ of pregnant women were aware of swine flu infection, $85(85 \%)$ of pregnant women knew that swine flu is due to viral infection while $65(65 \%)$ of pregnant women were aware that swine flu infection spreads through air while sneezing and coughing (Table $3)$.

Baria $\mathrm{HG}$ et al, reported that $86 \%$ science and $63.18 \%$ commerce students correctly knew the causative agent for swine flu. $84.5 \%$ (science) and $54 \%$ (commerce) students knew the other name of swine flu (H1N1). $61 \%$ (commerce) and 56\% (science) students knew about the availability of swine flu vaccine at government hospitals. $57 \%$ (science) and $40.30 \%$ (commerce) knew about availability of free treatment of swine flu at government hospitals. $^{12}$

In this study, 95 (96\%) of pregnant women knew fever as symptom of swine flu, $83(83 \%)$ of pregnant women knew cough and cold as symptoms while $64(64 \%)$ of pregnant women knew headache and body ache as symptoms (Table 4).

Shilpa $\mathrm{K}$ et al, found that fever as symptom was known to $82.6 \%$ while cough and cold was known to $72.3 \%$ and $55.4 \%$ of the respondents as a symptom respectively $2.7 \%$ of them had myth regarding spread of swine flu by eating pork, while $56.0 \%$ of the respondents said it was by inhalation and close contact with the infected. $50.5 \%$ of the participants knew there was treatment available for swine flu, while only $10.3 \%$ of them had heard about the drug Tamiflu. ${ }^{13}$

In this study, $94(94 \%)$ of pregnant women were aware that vaccination against swine flu can prevent swine flu infection. $80(80 \%)$ of pregnant women knew that covering mouth and nose while coughing and sneezing can prevent spread of swine flu infection while $52(52 \%)$ of pregnant women knew that frequent hand washing helps in preventing spread of swine flu infection (Table 5).

Kakade NR found that $18(20 \%)$ student are had poor knowledge, the majority $31(62 \%)$ had average knowledge and 9 (18\%) had good knowledge regarding swine flu and its protective measures. ${ }^{14}$

In this study, $76(76 \%)$ of pregnant women received vaccination against swine flu while $24(24 \%)$ of pregnant women did not receive vaccination against swine flu (Table 6).

Fifty-seven percent of pregnant women $(n=34)$ participating in the survey choose not to be immunized. Among the forty-three percent $(n=26)$ receiving the influenza immunization. $20 \%$ received the immunization before pregnancy, $15 \%$ during the first trimester, $6.7 \%$ during the second trimester, and $1.7 \%$ during the third trimester. $^{15}$

\section{CONCLUSION}

The practices for swine flu were not adequate. Despite having acceptable knowledge and attitude positive practices needs to be encouraged. Pregnant women should be well informed about the earliest appearing symptoms of swine flu. So, that they can go for medical check-up on appearance of the symptoms.

Though awareness about vaccination was good, some pregnant women did not receive vaccination either because of myths, fear or monitory constraint. 
Funding: No funding sources

Conflict of interest: None declared

Ethical approval: The study was approved by the Institutional Ethics Committee

\section{REFERENCES}

1. Scalera NM, Mossad SB. The first pandemic of the $21^{\text {st }}$ century: a review of the 2009 pandemic variant influenza A (H1N1) virus. Postgrad Med. 2009;121(5):43-7.

2. Harper SA, Fukuda K, Uyeki TM, Cox NJ, Bridges $\mathrm{CB}$ Prevention and control of influenza: recommendations of the advisory committee on immunization practices (ACIP). MMWR Recomm Rep. 2004;53:1-40.

3. New Delhi: MOHFW. Ministry of Health and Family Welfare, India. Information on Swine Flu. Available at: http://www.mohfw.nic.in/swineflu.htm. Accessed $18^{\text {th }}$ April 2013.

4. Jamieson DJ, Theiler RN, Rasmussen SA. Emerging infections and pregnancy. Emerging Infect Dis. 2006;12:1638-43.

5. Pierce M, Kurinczuk JJ, Spark P, Brocklehurst P, Knight M. Perinatal outcomes after maternal 2009/H1N1 infection: national cohort study. BMJ. 2011;342:d3214.

6. Jamieson DJ, Honein MA, Rasmussen SA, Williams JL, Swerdlow DL, Biggerstaff MS, et al. H1N1 2009 influenza virus infection during pregnancy in the USA. The Lancet. 2009;374(9688):451-8.

7. Guidance on Swine Flu (H1N1v) for pregnant mothers - a joint statement from the Royal College of Obstetricians and Gynecologists and the Royal College of Midwives, RCOG/RCM. 2009.

8. Consensus statement for $\mathrm{H} 1 \mathrm{~N} 1$ in pregnancy, H1N1 in pregnancy - Fogsi, 2014. Available at: www.fogsi.org/wp-content/uploads/2015/11/h1n1 _in_pregnancy.pdf. Accessed $18^{\text {th }}$ January 2020.

9. Mosby LG, Rasmussen SA, Jamieson DJ. 2009 pandemic influenza A (H1N1) in pregnancy: a systematic review of the literature. Am J Obstet Gynecol. 2011;205(1):10-8.

10. Torres-Ramírez A. Pandemic influenza caused by A (H1N1) in pregnant women. Ginecologia y obstetricia de Mexico. 2010;78(02):121-7.

11. Balkhy HH, Abolfotouh MA, Al-Hathlool RH, AlJumah MA. Awareness, attitudes, and practices related to the swine influenza pandemic among the Saudi public. BMC Infect Dis. 2010;10(1):42.

12. Baria HG, Solanky P, Shah H, Patel R. A study on swine flu (H1N1) awareness among college students of Valsad city. Inter J Comm Med Pub Health. 2017;4(10):3668-72.

13. Shilpa K, Kumar BP, Kumar SY, Ugargol AR, Naik VA, Mallapur MD. A study on awareness regarding swine flu (influenza A H1N1) pandemic in an urban community of Karnataka. Med J Dr. DY Patil Univer. 2014;7(6):732.

14. Kakade NR, Kakade SV. A study to assess the effectiveness of the structured teaching programme, on knowledge regarding swine flu among secondary school going children in selected school at Karad. Age. 2014;13(4):8.

15. Puchalski S, Hollema C, Marshall B. Current Attitudes and Practices among Pregnant Women toward Influenza Immunization. J Preg Child Health. 2015;2:184.

Cite this article as: Doshi N, Upadhye AJ, Upadhye JJ. Swine flu awareness in pregnancy. Int J Reprod Contracept Obstet Gynecol 2020;9:1981-5. 